\title{
Ermeni Sorunu'nun Ortaya Çıkış Sürecinde Bir Ermeni Aydını: Minas Çeraz ve Yurtdışındaki Faaliyetlerinin Analizi
}

Fikrettin Yavuz ${ }^{*}$

(ORCID ID: 0000-0002-3161-457X)

Büşra Beyhan $^{* *}$

(ORCID ID: 0000-0003-3330-6447)

\author{
Makale Gönderim Tarihi \\ 01.09.2019
}

\author{
Makale Kabul Tarihi \\ 20.09.2019
}

\section{Özet}

19. yüzyılın başından itibaren Osmanlı Devleti'nin en önemli sorunlarından biri milliyetçilik cereyanına paralel olarak gelişen gayrimüslim tebaanın bağımsızlık hareketleri olmuştur. Yunan, Bulgar ve Ermeni örneklerinde bu hareketlerin bayraktarlıklarını kiliseler ve din adamları, komiteler ve öğretmenler gibi milletlerini etkileme konumunda bulunanlar yapmıştır. Ermenilerin özerklik/bağımsızlık isteklerinde meselenin uluslararası boyuta taşınması ve dünya kamuoyunda tanınmasında birçok Avrupa ülkesi ve Amerika'daki faaliyetleriyle karşımıza çıkan önemli simalardan biri de çok yönlü bir şahsiyet olan Minas Çeraz'dır. 1852-1929 yılları arasında yaşamış olan Çeraz, Ermeni Sorunu'nun gelişim sürecindeki simalardan biri olarak eğitim hayatını müteakip önce Ermeni Patriği Genel Sekreteri ardından Berlin Kongresi'ne patrikhane tarafından gönderilen heyetin tercümanı olarak görev almıştı. Bu süreçteki çabalarından memnun kalan dönemin Patriği Nerses Varjabedyan, onu heyetin Berlin'den dönmesinden bir süre sonra, Londra'da Ermeniler adına çeşitli temaslarda bulunmak üzere İngiltere'ye gönderdi. Daha sonra, "Ermenilerin temsilcisi" olarak 1893'te Chicago Dünya Dinleri Konferansı ve ardından 1899 'da Lahey Barış Konferansı gibi uluslararası toplantılara katılan Çeraz'ın önemli bir özelliği de önce İngiltere'de ardından Fransa'da yayınladığı "L’Arménie" dergisi ile Osmanlı Devleti'ne karşı yürüttüğü yayın faaliyeti olmuştur.

* Doç. Dr., Sakarya Üniversitesi, Fen-Edebiyat Fakültesi, Tarih Bölümü, fyavuz@sakarya.edu.tr.

** Yüksek Lisans Öğrencisi, Sakarya Üniversitesi, Sosyal Bilimler Enstitüsü, Türkiye Cumhuriyeti Tarihi Bilim Dalı, bursa.beyhan@ogr.sakarya.edu.tr.

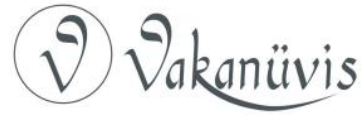


Bu makalenin amacı Ermeni Davası için daha birçok görev ve sorumluluk üstlenen Minas Çeraz'ın Ermeni Sorunu'nun ortaya çıkış sürecinde özellikle Batı kamuoyunu kazanmaya yönelik faaliyetlerinin genel bir çerçevesini çizmek ve böylece Çeraz örneğinde dönemin Ermeni aydınlarının meseleye bakışlarını analiz etmektir.

Anahtar Kelimeler: Minas Çeraz, Ermeni Sorunu, L'Arménia, Propaganda, Basın.

An Armenian Intellectual in the Emergence of the Armenian Question: An Analysis of Minas Tcheraz and His Activities in Abroad

\section{Abstract}

Since the beginning of the 19th century, one of the most important problems of the Ottoman Empire was the independence movements of her non-muslim subjects that developed in parallel with the idea of nationalism. The pioneers and leaders of these movements in the Greek, Bulgarian and Armenian examples were their churches, and those who influenced their nation, such as clergyman committees and teachers. One of the most important figures in bringing the Armenian Issue to the international dimension and recognition in the World public opinion for the Armenian autonomy/independence was Minas Tcheraz, an all-rounder, with his activities both in many European countries and the United States. Lived in between 1852 and 1929 and as one of the figures in the development process of the Armenian Question, Tcheraz served at first following his education as the Secretary General of the Armenian Patriarchate and then as the interpreter of the delegation sent to the Congress of Berlin by the Patriarchate. Following the Berlin mission, Patriach Nerses Varjabedian, satisfied with his efforts, sent him to England for various contacts in London on behalf of the Armenians. Afterwards, Tcheraz participated in international meetings such as the Chicago World Religions Conference in 1893 and later in 1899 The Hague Peace Conference as the "representative of the Armenians". Another important feature of Tcheraz was the publication activities with his journal "L'Arménie", first published it in England and then in France, against the Ottoman Empire.

This article aims to provide a frame of the activities of Minas Tcheraz, in particular gaining the Western public opinion, who assumed numerous duties and responsibilities during the emergence of the Armenian Question, and thus to analyze in the case of Tcheraz the views of the Armenian intellectuals of the period towards the Armenian Question.

Keywords: Minas Tcheraz, Armenian Question, L'Arménia, Propaganda, Press.

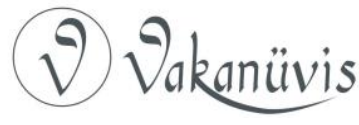




\section{Giriş}

Fransız İhtilali'den günümüze dünyayı şekillendiren milliyetçilik fikrinin neticesi olarak zuhur eden ayrılıkçı hareketler, 19. yüzyıla damgasını vurmuş, bu durumdan en fazla etkilenen devletlerden birisi de Osmanlı Devleti olmuştur. Aslına bakııısa etnik milliyetçilik, yüzyılın başından itibaren Osmanlı azınlıkları arasında yayılmış ve bunun neticesinde azınlıklar arasında bağımsızlık hareketleri baş göstermişti. Sırp, Yunan, Bulgar ayrılıkçı hareketlerini Ermeni ayrılıkçı hareketi takip etmiştir. Özerklikten bağımsızlığa giden talepleri için Avrupalı devletlerin desteğini almak adına benzer süreçler işleten tüm ayrılıkçı hareketlerin öncülügünü, genellikle kilise, din adamları, gizli komiteler ve söz konusu milletlerin önde gelen entelektüelleri yapmıştır. Ermeni örneğine bakıldığında da benzer unsurların ön planda olduğu görülmektedir. Özerklik taleplerinden bağımsızlık isteğine bu süreçte Ermeni Sorunu'nun uluslararası bir hüviyet kazanıp dünya kamuoyunda daha bilinir hale gelmesini sağlayanlar arasında 19. yüzyılın ikinci yarısında İstanbul Ermeni Patrikliği yapan Mıgırdıç Kırımyan, Nerses Varjabedyan ve Mateos İzmirliyan gibi ruhaniler, Ermeni komitelerinin teşkilatlanmasının fikir babası olan Mıgırdıç Portakalyan gibi onlarca simadan bahsedilebilir. Ermeni Sorunu'nun dünya siyaset sahnesinde yerini aldığı yüzyılın son çeyreğinde ön plana çıkanlardan biri de tercüman, yazar, gazeteci, öğretmen gibi birçok özelliğe sahip ve bu süreçteki faaliyetleriyle adeta bir siyasetçi figürü çizen Minas Çeraz'dır ${ }^{1}$.

Eğin'li bir ailenin çocuğu olarak 25 Temmuz 1852'de İstanbul Hasköy'de dünyaya gelen ve babasını erken yaşta kaybeden Minas Çeraz'ı, geçimini dikiş nakış işleri yaparak sağlayan annesi büyütmüştür ${ }^{2}$. Hasköy'de tanınan bir aileye olan Çerazların kökeni, Eğin'in Abuçeh kasabasında bulunan "Çeraz" mahallesinden Pilibbos Amira'ya kadar

\footnotetext{
1 Minas Çeraz'ın Ermenice yazılışının (Uhumu 2tinuq) tam çevrilememesi gerek döneminde gerekse sonrasında adının farklı şekillerde geçmesine sebep olmuştur. Kaynaklarda Minasse Tchéraz, Minas Tchéraz, Minas Çiraz ve Minas Çeraz gibi değişik şekillerde geçmektedir. Kendisi uzun yıllar İngiltere ve Fransa'da yaşadığı ve buralarda "Minas Tchéraz" olarak tanındığı için, kitap ve makalelerinde bu soyadını kullanmıştır. Adı Batı Ermenilerince Çeraz şeklinde transkribe edildiği için biz de çalışmamızda Minas Çeraz şeklini tercih ettik.

2 Annie C. Marshall , "Minas Cheraz, A Biographical Sketch", Armenia, Vol. XI., No. 8., March 1913, s. 240.
}

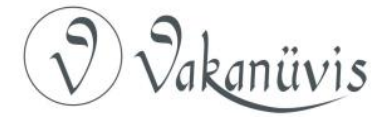


uzanmaktadır. Pilibbos Amira'nın oğlu olan ve İstanbul'da "Sarraflar Kahyalığı"na kadar yükselen Minas Amira Çerazyan, aile üyelerinin sarraflıkla iştigal etmelerinin önünü açmıştır ${ }^{3}$. Sarraf bir aileden gelen Minas, okul hayatına Nersesyan Mektebi'nde başlamış daha sonra erkek kardeşi Kaspar Çeraz ile Nubar-Şahnazaryan Mektebi'ne devam etmiştir ${ }^{4}$. Çeraz buradaki eğitimi sırasında halkların tarihine ve TürkErmeni ilişkilerine daha fazla ilgi duymaya başlamış, aynı zamanda dil konusunda da kendini geliştirmiştir. Eğitim hayatını tamamladığında Türkçe ve anadili Ermenicenin yanına akıcı bir şekilde konuşabildiği Fransızca, İngilizce ve Yunanca dillerini de ekleyebilmiştir. Çok dilliliğinin ileride kendisine birçok kapıyı açacak önemli bir özelliği olduğunu söylememiz gerekir ${ }^{5}$. Eğitim hayatı esnasındaki kazanımları bir Ermeni aydın olarak Çeraz'ın eğitimci, gazeteci, yazar ve siyasi bir figür olarak çok yönlü bir portre çizmesine vesile olmuştur. Çeraz böylelikle Ermeni Sorunu bağlamında gerek kendi cemaatinde gerekse Türk ve Dünya kamuoyunda devrinde en tanınan simalarından biri haline gelmiştir.

Çeraz'ın eğitim hayatını tamamladığı dönem Ermeni Sorunu'nun yeni bir evreyi girdiği sürece denk gelmektedir. Mezuniyetini müteakip bir süre öğretmenlik yaptıktan sonra dönemin İstanbul Ermeni Patriği Nerses Varjabedyan'ın sekreterliğine getirilmiştir 6 . İşte bu tayin Çeraz'ın bu tarihten sonraki kaderini çizmiş ve ölümüne değin hayatını Ermeni Sorunu'nun bilhassa dünya kamuoyunda tanınmasına adamıştır.

\footnotetext{
${ }^{3}$ Mesela ailenin tanınan simalarından biri olan Hacı Kevork Amira Çerazyan da, sarraflık mesleğini sürdürmüştür ve 1802 ' de vefat eden Kevork'un evliliğinden iki erkek çocuğu olmuştur: Kaspar Amira Çerazyan ve Krikor Amira Çerazyan. Ermeni cemaatine yaptığı maddi ve manevi katkıları dışında Krikor Amira Çerazyan ile ilgili günümüze başka bir bilgi ulaşamamıştır. Kardeşi Kaspar Amira Çerazyan ise Tepedelenli Ali Paşa'nın sarrafı olmuş ancak paşanın tutuklanmasından kısa bir süre sonra, Valide Han'ın kapısında 1821 yılında asılarak idam edilmiştir. "Deli Bağdasar" olarak tanınan oğlu Bağdasar Amira Çerazyan da baba mesleğini devam ettirmiş, hatta amcası Krikor gibi Ermeni cemaatine maddi-manevi katkılarda bulunmuştur. 1854 yılında vefat eden Bağdasar Amira'nın tek erkek çocuğu olan Kaspar Çerazyan ise 1852 'de, o dönemde yaşanan kolera salgınına yakalanarak hayatını kaybetmiştir. Kevork Pamukciyan, Biyografileriyle Ermeniler, Aras Yayıncılık, İstanbul, 2003, s. 163-165.

${ }^{4}$ Pamukciyan, Biyografileriyle Ermeniler, s. 163.

${ }^{5}$ Marshall, "Minas Cheraz, s. 240.

${ }^{6}$ Pamukciyan, Biyografileriyle Ermeniler, s. 163.
}

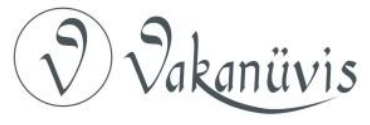




\section{Berlin Kongresi'nden Lahey Barış Konferansı'na Minas Çeraz'ın Faaliyetleri}

Balkan Krizi neticesinde meydana gelen 93 Harbi ve Ayastefanos Antlaşması, bu antlaşmanın İngiltere'nin siyasetine aykırılığı neticesinde değiştirilmesi için Berlin'de bir kongre toplanması ile bu kongreye Ermeni Patrikhanesi'nin bir heyet gönderme kararı, şüphesiz Minas Çeraz'ın hayatındaki önemli dönüm noktalarından biridir ${ }^{7}$. Patrik Nerses Varjabedyan dönemin Ermeni Milli Meclisi'nin izni ile heyetin teşkiline ve heyet içerisinde Ermeni meselesini yakından bilen kişilerin olmasına özen göstermişti. Bu çerçevede Eski Patrik Mıgırdıç Kırımyan, Beşiktaş Başpiskoposu Horen Narbey ile Stefan Papazyan ve Minas Çeraz heyete dahil edilmişlerdi ${ }^{8}$. Temel gayeleri Ermeni Sorunu'nda Büyük Devletlerin desteklerini alabilmek olan heyetten Kırımyan ile Çeraz Avrupa başkentlerine, Horen Narbey ise Petersburg'a ziyaret yaptıktan sonra heyetin bütün üyeleri Berlin'de bir araya gelmişlerdi ${ }^{9}$.

Roma, Paris ve Londra'da Ermeni Sorunu için faaliyet gösteren Eski Patrik ve tercümanı olarak yoğun çaba sarf eden Çeraz, Berlin'de de kongreye katılan devletlerin delegeleriyle her fırsatta görüşmeler yapmak isteğinde olmuşlardı. Bu çerçevede ilk olarak Dr. Maritz Busch ve Hohenlohe vasıtasıyla Şansölye Bismarck ile görüşmek istemişlerdi ${ }^{10}$. Ancak kendisi ile buluşarak bazı açıklamalar yapma taleplerini bildirmelerine rağmen, Bismarck sekreteri vasıtasıyla zamanı olmadığını ve başkan olarak tarafsı kalması gerektiğini ileri sürerek onları kabul edemeyeceğini bildirmişti ${ }^{11}$. Heyetin Berlin'de yaptığı her görüşmede tercümanlık görevini ifa eden Minas Çeraz, Ermeni Sorunu'na müspet yaklaştığını düşündükleri ve Fransa adına kongreye katılan Dışişleri

\footnotetext{
7 Çeraz'ın Berlin Kongresi'ne giden süreçteki faaliyetleri için ayrıca bkz. Serdar Sakin, "Minas Çeraz'ın (Minasse Tcheraz) Avrupa Temasları ve Berlin Kongresi İzlenimleri", Gazi Akademik Bakış, Cilt. 8, Sayı 16, 2015, s. 237-258.

8 Muşa Şaşmaz, British Policy and the Application of Reforms for the Armenians in Eastern Anatolia 1877-1897, Türk Tarih Kurumu, Ankara, 2002, s. 7.

9 H.M. Knadjian, The Eternel Struggle, Fresno Republican Printery, California, 1900, s. 45, V.G. Krbekyan, "Armyanskiy Vopros na Berlinskom Kongresse", Lraber Hasarakakan Gitut'yunneri, Yerevan, 2002, s. 26.

${ }^{10}$ A. O., Sarkissian, History of the Armenian Question to 1885, Urbana : the University of Illinois Press, 1938, s. 80.

11 Vardan Aramovic Parsamian, Istoria Armianskogo Naroda 1801-1900 gg. Erivan, 1972, s. 289.
}

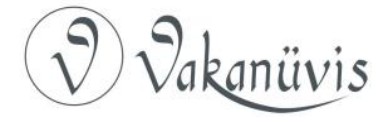


Bakanı Waddington ile bir görüşme gerçekleştirdi. Bu görüşme esnasında Çeraz ve Fransız Dışişleri Bakanı arasında geçen diyalogda Çeraz'ın sarf ettiği sözler, bu dönemde Ermeni bir aydının bağımsızlık konusundaki zihin dünyasını ortaya koyması açısından dikkat çekicidir. Waddington Çeraz'a, "Batı Ermenilerine bağımsızlık verildiği takdirde Doğu Ermenilerinin nasıl bir tavır sergileyeceklerini" sorması üzerine Çeraz, Doğu Ermenilerinin kardeşlerine kavuşmak isteyeceklerini veya en azından bir kısmının hemen Batı Ermenistan'a geçeceğini söylemişti ${ }^{12}$.

Berlin'de bir aydan fazla yoğun bir çaba sarf eden ve hemen her ülkenin temsilcisiyle görüşen heyet toplamda dört aydan fazla süren mesailerinin bir neticesi olarak Kongre'den en azından muhtar bir Ermenistan kararının çıkmasını arzu ediyorlardı. Ancak Berlin'de bu karar çıkmadı. Ayastefanos Antlaşması'nda yer alan 16. Madde Berlin'de 61. Madde'ye dönüştü. Ermeni kanaat önderleri arasında bu maddeyi "tamamen ölü bir unsur" olarak görenler ${ }^{13}$ olduğunu gibi, maddeye pozitif yaklaşanlar da oldu. Bu kişiler arasında yer alan Minas Çeraz "Berlin Kongresi'nde Ne Kazandık"14 adlı risalesinde Ayastefanos ile Ermeniler için sadece Rusya'nın sorumluluk aldığını, Berlin Antlaşması ile ise Rusya'nın yanı sıra Düvel-i Muazzama'nın Ermeni Sorunu için bir araya geldiğini vurguluyordu. Risalesinde ıslahat kararının sınırı olmayan bir lütuf olduğunu, ilgili devletlerin denetiminde Ermenilerin vatan ve yurtlarını ihya edebileceklerini ve ıslahat kararının gelecek için idari bağımsızık müjdeleyen bir cümle olduğunu ifade ediyordu ${ }^{15}$. Berlin'de çıkan ıslahat kararına olumlu bakan Minas Çeraz için bu süreç, hayatının dönüm noktalarından biri olmuştur. Nitekim bu tarihten sonra hayatının sonuna değin dünyanın çeşitli yerlerinde farklı görev ve sorumluluklarla farklı pozisyonlarda Ermeni Sorunu'nun savunucularından biri olmuştur.

Berlin'de sivrilmesi ona yeni kapılar açtı. Bu süreçteki çalışma ve performansından memnun kalan Patrik Varjabedyan, Çeraz'ı İngiliz

\footnotetext{
12 Krbekyan, "Armyanskiy Vopros na Berlinskom Kongresse", s. 33-34

13 Ramazan Erhan Güllü, Ermeni Sorunu ve Istanbul Ermeni Patrikhanesi (1878-1923), Türk Tarih Kurumu, Ankara, 2015, s. 73.

${ }^{14} \mathrm{Hem}$ bu risalesi hem de yine Berlin sürecinde başından geçenleri anlattığı Ermenistan ve İtalya adlı risalesinin özeti için bkz. BOA., Y.PRK.A., 3-25.

${ }^{15}$ Esat Uras, Tarihte Ermeniler ve Ermeni Meselesi, Belge Yayınları, İstanbul, 1987, s. 266269.
}

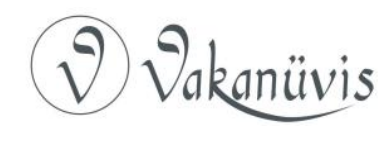


kamuoyunu kazanmak için Londra'ya gönderdi. Çeraz'a göre Patriği böyle bir karar almaya iten şey, İngiltere'de tekrar başa gelen William E. Gladstone'un Ermeniler için fazla bir şey yapamayacağını söylemesiydi. Patrik ise 1880'de tekrar Başbakan olan Gladstone'a özel bir elçi yollayarak, onu Ermeniler için ciddi bir eylem gerçekleştirmeye zorlayabileceğini düşünüyordu. Bu görev için seçilen Minas Çeraz dört aylığına Londra'ya gönderilmişti. Çeraz'ın söylediğine göre kendi isteğiyle ve herhangi bir ücret talep etmeksizin fazladan dört ay daha Londra'da kalmıştı. Başlangıçta Krikor Odyan'ın desteği ile İngiliz hükümeti ve ileri gelen siyasilerle çeşitli temaslar kurmaya çalışan Minas Çeraz, yaklaşık sekiz ay kaldığı İngiltere'de Ermeni Davası'na destek sağlamak için elinden geleni yapmıştı ${ }^{16}$.

Minas Çeraz İngiltere'de kaldığı süre boyunca gazeteci, devlet adamı, milletvekili ve ülke çapında tanınan birçok isimle görüşmüştür. Sadece Ingilizlerle değil orada bulunan ve etkili olabileceğini düşündüğü herkesle iletişime geçmek için elinden geleni yapan Çeraz, Fransızların en prestijli gazetelerinden biri olan Temps'in müdürü Adrien Hebrard ve İngiliz Pall Mall Gazette'nin müdürü John Morley ile görüşerek onları Ermeni Davası'na kazanmaya çalışmıştı. Çeraz kısa süre içerisinde ikinci kez geldiği İngiltere'de Ermeniler hakkında verdiği konferans ve gazetelerde çıkan röportajları ile İngiliz kamuoyunda tanınmaya başlandı. İngiltere'de bulunduğu süre zarfında James Bryce, Gladstone, Charles W. Dilke, J.A. Godley, Fitzgerald, Dr. S. Panaretoff ve F.W. Chesson gibi birçok tanınmış kişi ile yine, dük, lord ve leydi unvanı taşıyan İngiliz asilzade, aristokrat ve büyükelçi ve asker gibi onlarca insanla görüşmeler gerçekleştiren Minas Çeraz, İngiliz kamuoyunu Ermeni Davası'na kazanmak için durup dinlenmek bilmeden çaba göstermiştir ${ }^{17}$. Tüm bu çabaları kuşku yok ki Ermeni Sorunu'na bakışta İngiliz kamuoyunda müspet manada etkili oldu.

Londra'da geçen sekiz ayın ardından Minas Çeraz, İstanbul'a döndü. Burada kaldığı süre zarfında eğitimci kimliği ile birçok Ermeni okulunda edebiyat, dil ve tarih dersleri verdi. Ancak onu eğitim kariyerinde ön plana çıkaran, İstanbul Galata'daki Getronagan Ermeni Okulu'nda yaptığı yöneticiliği oldu. Bu okulda 1886 'da başladığı müdürlük görevi,

16 L'Arménie, "Une Mission Politique en Angleterre", 1 Janvier 1901, s. 3.

17 L'Arménie, "Une Mission Politique en Angleterre", 1 Mars 1901, s. 3-4.

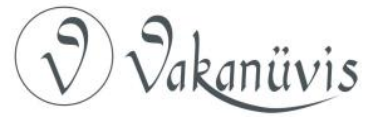


üç yıl sonra 1889 'da Londra'ya kaçması ile son buldu ${ }^{18}$. Çeraz'ın "gönüllü sürgün" olarak adlandırdığı Londra'ya kaçışının sebebi, kendisinin hükümetin saldırısına uğradığını düşünmüş olmasıdır. Dönemin İngiliz Büyükelçisi William White'ın verdiği pasaport ${ }^{19}$ ile kaçan Çeraz, Londra'da eğitime ve Ermeni Davası'na yönelik propaganda faaliyetlerine devam etti. Kendisine verilen destek sayesinde 1890'da Ingiltere'nin en eski ve prestijli okullarından biri olan King's College'da Ermeni kürsüsü kuran Minas Çeraz, bu gelişmenin ardından Avrupa ülkelerinde "Profesör Cheraz" olarak tanınmaya başladı". Ermeni Sorunu'nun yeni bir evreye girdiği, İstanbul ve Anadolu'da Ermeni komitelerinin sebep olduğu birçok isyanın yaşandığı 1890'lı yıllarda yurt dışında olan Minas Çeraz İngiltere'den sonra Yeni Dünya'da da Ermeni Davası için çaba sarf etmiştir.

Minas Çeraz'ın Amerika'ya adım atmasına vesile olan şey 1893 senesinde dünya tarihinde ilk kez Chicago'da Dünya Dinler Parlamentosu adıyla tertip edilen konferans oldu. Chicago'da 11-27 Eylül tarihleri arasında gerçekleştirilen bu toplantı ve sonrasında ABD'de bazı yerlere yaptığı ziyaretleri, Minas Çeraz için Ermeni Davası'nı anlatacağı bir sürece dönüştü. 9 Eylül günü Chicago'ya ulaşan Çeraz'ı şehrin önde gelen bir grup Ermenisi karşıladı ${ }^{21}$. Dr. Carl von Bergen'den sonra, Ermeni Kilisesi adına kongre sahnesindeki yerini alan Minas Çeraz, konuşmasında "zulüm altında acı çeken Hıristiyan Ermeniler" teması işledi ${ }^{22}$. Konferans'ın sonunda, Hıristiyanlığın ilerlemesi ve buradaki parlamento ruhunun devam etmesi adına bir "Hıristiyan Birliği Kardeşliği" teşkil edildi. Bu birliğin teşkili için hazırlanan belgenin ilk imzacıları arasında Roma Katolikleri ve Yunan Kilisesi dışında diğer tüm

\footnotetext{
18 Kevork B. Bardakjian, A Reference Guide to Modern Armenian Literature 1500-1920, Wayne State University Press, Detroit, 2000, s. 319.

19 Pasaportun İngiliz Büyükelçi tarafından verildiği birkaç yıl sonra bir Fransız gazetesinde yayınlanan haberde geçmektedir. Journal Des Debats, "Dernier Dépêches", 21 Avril 1893, s. 4.

${ }^{20}$ Agop J. Hacikyan vd., The Heritage of Armenian Literature Vol. III, Wayne State University, Detroit, 2005, s. 459.

${ }^{21}$ Chicago Daily Tribune, "Oriental Churcmen Begin a Conference in Chicago", 10 September 1893, s. 1.

22 Paul Carus, The Dawn of a New Religious Era, The Open Court Publishing Company, Chicago, 1916, s. 1, The World's Parliament of Religions Vol. I, (ed. John Henry Barrows), The Parliament Publishing Company, Chicago, 1893, s. 96.
}

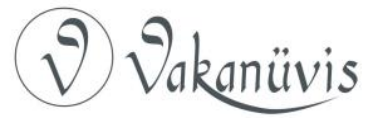


tanınmış kiliselerin temsilcileri vardı. Chicago'dan J. H. Barrows, Baptist ve United Brethen kiliselerinin temsilcileri olan Dr. J.D. Boardman ve Piskopos Mills ile bu kişiler gibi tanınmış birçok din adamının yanında imzası olanlardan biri de Minas Çeraz'dı ${ }^{23}$. Osmanlı yetkilileri Minas Çeraz'ın Amerika'daki bu toplantıya İstanbul Ermeni Patrikhanesi'nin temsilci olarak katılma duyumunu aldıktan sonra, konuyu yazışmalar yaparak derinlemesine araştırmış ve gidişinin Patrikhane ile ilgisinin olmadığı, durumun bu şekilde gerekli yerlere bildirilmesi kararına varmışt $\left.\right|^{24}$.

Bu toplantıdan sonra Çeraz, tıpkı İngiltere'de olduğu gibi Ermeni Davası için yoğun çaba sarf etti. Rhode Island, Providence'deki Brown Üniversitesi'nde dersler verdi. Üniversite kampüsünde bulunan Manning Salonu'nda "Ermenistan ve Ermeniler, Inançları ve Dilleri" başlıklı bir konferans verdi. İzleyicilerin merakını celbeden bu konferansından sonra, yerel bir yayın organı olan Providence gazetesinin Çeraz ile yaptığı röportaj, adının Amerikan kamuoyunda duyulmaya başlamasına vesile oldu. Şehre gelişinin dördüncü günü akşamı 8 Ekim 1893 'te yine Ermenilerle ilgili bir konferans veren Minas Çeraz, ertesi gün Profesör Homer'ın başkanlık ettiği bir toplantıya katılmak için Worcester Politeknik Enstitüsü'ne gitti. Ermenilerin sözcüsü gibi hareket eden Çeraz'a altın bir kalem hediye eden Worcester Ermeni Topluluğu'nun şu sözleri Çeraz'ın çevresinde meydana getirdiği etkiyi göstermesi açısından son derece dikkate şayandır: "Mürekkebiniz azalıyorsa, bu kalemi kanımızla doldururuz"25.

Amerika seyahatinden sonra Minas Çeraz, Fransa'da benzer faaliyetlerine devam etti. Lille, Nancy, Epinal ve Bar-la-Duc gibi şehirlerde konferanslarını sürdüren Çeraz, Paris'teki Coğrafya Derneği'nde de "Ermeniler, Ülkeleri, Tarihleri, Dinleri, Dilleri ve Edebiyatları" başlıklı bir konferans verdi ${ }^{26}$. Fransız basınının sempatisini kazanan Çeraz'ın bu konferansı La Liberté, La Lanterne, Le Grand Echo du Nord, Le Journal ve Les Nouvelles D'Orient gibi pek çok gazetede

\footnotetext{
${ }^{23}$ Rock Island Daily Argus, "A Move For Christian Unity", 22 September 1893, s. 4.

${ }^{24}$ BOA., YA.HUS. 281/103, BEO., 292/21830. HR.SYS. 2736/8.

${ }^{25}$ Varoujan Karentz, Mitchnapert the Citadel: A History of Armenians in Rhode Island, iUniverse, 2004, s. 38.

${ }^{26}$ Les Nouvelles D’Orient, "Conférence de M. Minas Tchéraz", 1 Avril 1895, s. 6.
}

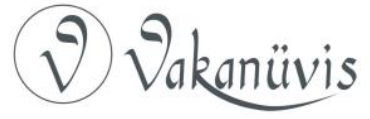


dikkatleri üstüne çekmişti. Çeraz Lille'de yaptığı konferansta, Ermenistan'ı, Fransa'da milli duyguları coşturan Alsas-Loren bölgesi ile kıyaslayarak, Fransızların kalbini kazanmaya gayret etmişti. Ona göre Ermenistan, dört nesilden beri Müslüman boyunduruğu altında gözyaşı döküyordu ve kendilerine yapılan hiçbir şeyi de unutmuyorlardı. Ermeni Sorunu'nu bu şekilde gündeme taşımak gayreti içerisinde olan Çeraz, konuşmasını Ermenilerin Haçlı Seferleri'nde Fransızların yanında kanlarını döktüklerini ve 1870'de Almanya'ya karşı savaşan Fransa'nın yanında yine gönüllü Ermenilerin bulunduklarını hatırlatarak bitirmişti ${ }^{27}$.

Minas Çeraz'ın Avrupa'da Ermeni propagandasını yapmak için katıldığı toplantılardan bir diğeri de 1899 'da Hollanda'nın Lahey şehrinde gerçekleştirildi. Pek çok ülkeden ve farklı kesimlerden katılımcının olduğu, Lahey Barış Konferansı'na Bulgaristan Ermenileri tarafından delege sıfatıyla gönderilen Minas Çeraz, 20 Mayıs 1899'da Lahey'e ulaştı. Gelir gelmez işe koyulan Çeraz, Konferans Başkanı ile Ermeni Sorunu hakkında bir görüşme gerçekleştirdi ${ }^{28} .22$ Mayıs 1899' da Rusya delegesi olan Raffalovich'e yazdığı mektupta Çeraz, konferanstaki asıl gayesinin ne olduğunu net bir şekilde ortaya koyuyordu. Barış Konferansı'na, davasını savunmak için otuz Ermeni kolonisi tarafından gönderildiğini söyleyen Çeraz, Raffalovich'ten yüz yüze beş dakika görüşme talebinde bulundu. Çeraz'ın görüşmek istediği Fransa, Avusturya-Macaristan ve Almanya'nın konferansa katılan delegeleri ise Çeraz'ın gönderdiği mektuplara cevap dahi vermemişlerdi ${ }^{29}$.

Konferansta Osmanlı Devleti'nin Ermenilere yaptığı "zulmü" dile getirmek isteyen Çeraz'a, 27 Mayıs tarihinde Barış Konferansı Genel Sekreteri'nin gönderdiği mektupta, politik sorunların konferansın gündemine alınmadığı bildirilmişti. Bu olumsuz cevaba rağmen Çeraz bu konudaki ısrarını devam ettirdi. Öyle ki, Konferans Genel Sekreteri'ne tekrardan bir mektup göndererek, kendisinin "Bab-ı Ali'yi, binlerce Ermeni insanını temsil etme göreviyle suçlamaya hakkı olduğunu" ve "Avrupa diplomasisinin bencilliğinin kurbanı olan Ermenistan'ın

\footnotetext{
27 Le Grand Echo du Nord, "Lille", 8 Mars 1895, s. 2.

${ }^{28}$ Le Temps, "La Conférence de la Paix", 22 Mai 1899, s. 2.

${ }^{29}$ L'Arménie, "La Conférence de la Paix", 1 Juillet 1899, s. 1.
}

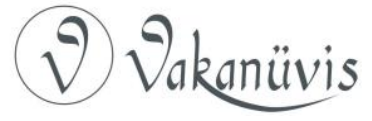


vaatlerini hatırlatmak için her zaman sesini yükselteceğini" ifade etmişti ${ }^{30}$.

Konferans Genel Sekreterliği'nce talebi reddedilen Minas Çeraz, bu sırada basına verdiği demeçlerde haklı olduğuna vurgu yaparak Ermeni Davası'nı savunmaya devam etti. Gerek Jön Türklerin lideri konumundaki Ahmed Rıza'nın Lahey'de oluşu, gerekse Minas Çeraz'ın faaliyetleri İstanbul'un takibinden kaçmıyordu. Özellikle İngiliz gazetelerinde bu konu hakkında çıkan haberlere göre Sultan Abdülhamid, Diran Kelekian adlı özel temsilcisini Ahmet Rıza ve Minas Çeraz'ın niyetlerini öğrenmek üzere Lahey'e göndermişti ${ }^{31}$. Bu ve bunun gibi haberlerle Avrupa kamuoyunda Minas Çeraz ve Ermeni Davası daha fazla duyulur hale gelmişti.

Barış konferansında istediklerini elde edemeyen Minas Çeraz'a Lahey ve Amsterdam'dan konferans vermesi için çeşitli davetler gelmişti. Ancak daha sonra Lahey polisi bu konferansların iptal edilmesi için tedbirler alma yoluna gitti. Belediye'den izin alınmadığı gerekçesiyle Çeraz'ın konuşmasına müsaade edilmemişti ${ }^{32}$. Ermeni Gençlik Merkezi'nde verilecek olan bu konferansın yasaklanması Amsterdam'da yayınlanan Dagblad, Familieblad, Haagsche Courant, Nieuws Van Den Dag, Algemeen Handelsblad gibi pek çok gazetede tepki haberlerine neden oldu ${ }^{33}$. Bu olayın üzerine Minas Çeraz Paris'e dönmeye karar vermişti ancak Konferans ikinci Meclis üyelerinden olan solcu Dr. Kuijper (Kuyper) ve liberal Liettinck'in müdahalesi ile Minas Çeraz, Amsterdam'da Ermenistan ve Ermeniler hakkında bir konferans vermeyi başard ${ }^{34}$. Solcu ihtilalci grubun lideri olan Dr. Kuijper, Minas Çeraz'ın önündeki engeli kaldırarak, vereceği konferansa da başkanlık etmiştir ${ }^{35}$.

Konferansın yapılmasını sağlayan Hollanda Genel Meclis Üyesi ve konferansın da başkanlığını yapan Dr. Kuyper, Çeraz'ı konuşma yapmak üzere davet ederken, korkmadan söylemek istediği her şeyi söylemesini

\footnotetext{
30 L'Arménie, "La Conférence de la Paix", 1 Juillet 1899, s. 2.

${ }^{31}$ Leamington Spa Courier, "Armenia and The Peace Conference", 3 June 1899, s. 2.

${ }^{32}$ Le Journal des Débats Politiques et Littéraires, "Lettres de la Conférence", 4 Juin 1899,

s. 2.

33 L'Arménie, "La Conférence de la Paix", 1 Août 1899, s. 1.

${ }^{34}$ Le Temps, "La Conférence de la Haye", 5 Juin 1899, s. 1.

35 Le Temps, "Lettre Des Pays-Bas", 15 Septembre 1890, s. 3.
}

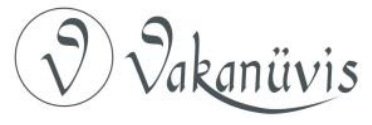


ve sorumluluğun kendilerinde olduğunu ifade etti. Kürsüye gelen Çeraz Ermeni Sorunu merkezli birçok hususa değindiği uzun bir konuşma yaptı. Öncelikle Ermenistan tabir ettiği coğrafyanın konumundan, bu bölgenin Doğu ve Batı́nın kanlı rekabetlerinin bir savaş alanı olduğundan ve o sıradaki Polonya gibi üç imparatorluk Türkiye, Rusya ve İran arasında bölündüğünden bahsetmişti.

Davasına destek almayı amaçlayan Çeraz konuşmasında, Ermenilerin Felemenklere yönelik sempatilerinin üç yüz yıllık bir geçmişe sahip olduğunu vurgulamış ve öteden beri iki millet arasındaki etkileşimine de değinmiştir. Ermenilerin, Doğu ve Batı arasında köprü vazifesi gördüğünü, özellikle Avrupa ticaretinin gelişmesinde etkilerinin olduğunu belirten Çeraz, Ermenilerin Amsterdam'da da bir koloni kurarak, ticari faaliyetlerde bulunduğunun altını çizmiştir.

Dinleyicilerin dini duygularına hitap etmeyi de ihmal etmeyen Minas Çeraz'ın konuşmasında Hıristiyanlık vurgusu dikkati çekmektedir. Hıristiyanlığı kabul eden en eski milletlerden biri olduğunu söylediği Ermenilerin, bu sebeple Müslüman denizi olarak tasvir ettiği Arap, Pers, Tatar, Türkmen, Kürt, Laz ve Türklerce yok edilmek istendiğini ileri sürüyordu. Konuşmasında Ermenilerin yalnızca can, mal ve namus güvencesi talep ettiklerini söyleyen Çeraz, Paris Antlaşması ile umutlandıklarını, ancak bu taahhüdün "ölü bir mektup” gibi kaldığını, Ayastefanos Antlaşması'nın 16. Maddesi ile umutlarının tekrardan yeşerdiğini dile getirdi. Ancak bu maddenin daha sonra Berlin Antlaşması'nın 61. Maddesi ile değiştirildiğini söyleyen Çeraz, Kıbrıs Konvansiyonu'na da imza atıldığını; ve fakat verilen sözlerden hiçbirinin tutulmadığını ifade ettikten sonra, Sultan Abdülhamid'in en temel reformlar için bile adım atmadığını, Kürtleri ve Türkleri Ermenilere karşı harekete geçirdiği şeklindeki iddialarını sıraladı ${ }^{36}$. Çeraz konuşmasının ilk kısmında Ermeni halkının iyi haslet ve değerlerinden, insanlık ve Hıristiyanlık için yaptıklarından bahsettikten sonra ikinci kısmında hak etmedikleri zulümlere maruz kaldıklarını, bunun sebebini ve buna karşılık taahhüt edilip de yapılmayanlar ile nihayet Ermenilerin nasıl bir yola başvurduklarının altını çizdi.

${ }^{36}$ Minas Tchéraz, Conférence Arménienne a Amsterdam, Libraire Höveker\&Wormser, Amsterdam, 1899, s. 6-15.

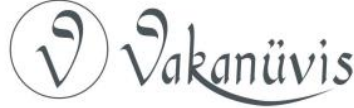


Konuşmasının bu kısmında daha sonra ortaya çıkan Ermeni komitelerinin teşkil sebeplerine değinen Çeraz, yasal yollarla taleplere cevap verilmeyince Ermeni cemaati içerisinden çıkan gençlerin yeni bir yola başvurduklarını ifade etmekteydi. Söylediğine göre bir grup genç Ermeni, soydaşlarına, ne Babıali'nin "despotik" hükümeti ne de Avrupa'nın "bencil" hükümetlerinden bir şey beklememek gerektiğini, yapılması gereken şeyin kendilerine zarar verenlere darbe vurmak olduğunu telkin etti. Böylece komitelerin kurulma süreci hakkında bilgi veren Çeraz bu hareketin öncülerinden biri olan Mıgırdıç Portakalyan'ın Ermeni Vatanperver Komitesi'ni teşkil ettiğini, Marsilya'da Armenia gazetesini kurarak bu dergiden etkilenen gençlerin daha sonra Cenevre'de teşkilatlanarak Hınçak (Çan) ve Droşak'ı (Bayrak) kurduklarını belirtmişti.

Konuşmasının bundan sonrasına Ağustos 1894 'te baş gösteren Sasun İsyanı ve daha sonra meydana gelen olaylardan bahsederek devam eden Çeraz, kamuoyunda Ermeni Davası'na taraftar kazanmak adına kendisini dinleyenleri de muhtemelen şaşkına çevirecek bir anlatım ve tasvir sergiledi. Anlatımında Türklerin barbarlığına vurgu yapan Çeraz, Ermenileri katledenin Osmanlı hükümeti olduğunu ileri sürerken, işkence, kazığa oturtma, diri diri yakma ve maktullerin derisini yüzme gibi insanlık dışı suç isnadında bulunan kişilerden alıntılar yapıp bu şekilde katledilenlerin sayısının kadın, erkek ve çocuk 300.000 civarında olduğunu ileri sürdü. Söylediklerinin inandırıcı olması için bazı propaganda kaynaklarında tasvir edilen vahşi öldürme yöntemlerine dahi örnekler veren Çeraz'ın anlattıkları, iddianın ötesinde kabul edilebilir şeyler değildir. Vahşetin ötesindeki bu iddialara göre Ermeniler çıplak vücutları balla kaplanarak direklere asılır, arıların ve böceklerin onları ölene kadar sokmasına izin verilirdi; duvara çivilenen Ermeni çocuklarının kafalarına ısıtılmış bakır vazolar şapka diye takıııdı ${ }^{37}$.

Konuşmanın bundan sonraki kısmında Avrupalı aydın ve şairlerin benzerlerinin Ermeni milleti içerisinden de çıktığını söyleyerek Bedros Toryan ve Kamar Katiba'nın milliyetçi Ermeniliği öven şiir ve yazılarından örnek pasajlar aktaran Minas Çeraz daha sonra Avrupalıların kendi çıkarları için Ermeni Sorunu'na gerekli ilgiyi göstermediklerinin, Lahey

${ }^{37}$ Tchéraz, Conférence Arménienne, s. 16-20.

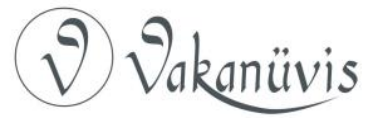


Konferansı'na kabul edilmeyişi ve bu süreçte yaşadığı hayal kırıklıklarının altını çizdi ${ }^{38}$.

Konuşmasının genelinde olduğu gibi Ermenilerin suçsuz yere devlet eliyle katledildiği vurgusuna dikkat çeken Minas Çeraz, dinleyicilerin duygularını da hedef alan ve aynı zamanda alkışlarla karşılanan şu sözlerle konuşmasına son verdi: "300.000 şehidimizin anneleri, eşleri, kız kardeş ve kız evlatları adına önünüzde diz çökerek yalvarıyorum, cellatlarımızın temsilcilerinin meleklere özgü beyaz ellerinizi öpmelerine müsaade etmeyin"39. Çeraz'ın faaliyetlerini yakından takip eden Osmanlı Hariciyesi Lahey'de yaptığı ve Osmanlı'ya yönelik olumsuz ifadeler içeren konuşmasının detaylarını Lahey sefareti ve şehbenderlik vasıtasıyla elde etmişti ${ }^{40}$.

Çeraz'ın ardından konferansın başkanlığını yapan Dr. Kuyper söz alıp bir konuşma yaptı. Teşekkür mahiyetindeki konuşmasının sonunda söyledikleri Minas Çeraz'ın anlattıklarının ne denli etkili olduğunu göstermesi açısından önemlidir. Nitekim Kuyper sözlerini "Yaşasın Ermenistan" şeklinde tamamlamıştı ${ }^{41}$. Çeraz ve Kuyper'in Lahey'de başlayan dostlukları devam etmiş, Kuyper 1901'de Hollanda Başbakanı olduğunda, Çeraz'ın Paris'ten yolladığı tebrik mesajlarını bütün Hollanda gazeteleri manşetlerine taşımıştı ${ }^{42}$.

Ermeni Sorunu'nun farklı boyutlar aldığı Berlin Kongresi'nden başlayıp 1880 ve 1890'lı yıllarda Minas Çeraz, Avrupa'da ve Amerika'da birçok toplantıya iştirak ederek, devrin Ermeni komitelerinin de temel gayesi olan Ermenileri bağımsız bir devlet çatısı altında toplama misyonuyla hareket etmişti. Minas Çeraz Berlin Kongre'sine giden heyetle başladığı bu yolda birçok konferansa katılmış, toplantılara iştirak etmiş ve kürsülerde konuşmalar yapmıştır. Doğrusu Minas Çeraz'ın bu faaliyetleri batı kamuoyunda Ermeni Sorunu'nu daha görünür kılmıştır. Çeraz bu tür toplantı ve konferanslarının yanısıra gazeteci kimliği ile Avrupa ve Amerikan gazetelerine haber olmuş, verdiği röportajlarla basın üzerinden de Ermeni Davası'nın propagandasını yapmıştır. Bu

\footnotetext{
38 Tchéraz, Conférence Arménienne, s. 21-29.

39 Tchéraz, Conférence Arménienne, s. 30.

40 BOA., Y.PRK. HR. 27/93-94, Y.MTV. 193/33.

41 Tchéraz, Conférence Arménienne, s.32.

${ }^{42}$ BOA., HR. SYS. 2751/16.
}

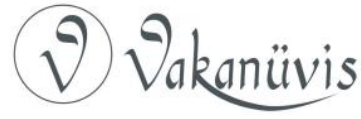


çerçevede önce İngiltere daha sonra Fransa'da yayınladığı dergisi ile Ermeni Sorunu'nun batı kamuoyunda duyulmasına çok önemli katkılar sağlamıştır.

\section{L'Arménie ve Basında Propaganda Faaliyetleri}

Ermeni Sorunu'nu batıda kamuoyunda tanıtmak, bir anlamda propagandasını yapmak amacıyla ilk gazete Mıgırdıç Portakalyan tarafından 1885 senesinde Marsilya'da Armenia adıyla yayınlandı ${ }^{43}$. Portakalyan gibi Ermeni propagandasının öncülerinden biri olan Karabet Agopyan, İngiltere'de $1888^{\prime}$ de kurduğu Ermeni Vatanperver Cemiyeti'nin yayın organı olarak "Hayastan" adlı bir gazete yayınladı ${ }^{44}$. Ertesi yıl Minas Çeraz yine aynı cemiyet bünyesinde L'Armenie ismiyle uzun yıllar yayınlayacağı dergisini çıkarmaya başladı. ílk sayısı 15 Kasım 1889 tarihinde yayınlanan dergi aralık 1905 'te 206. sayısıyla yayınına son verdi. Çeraz Mayıs 1898'e kadar Londra merkezli olarak yayınladığı dergisini Paris'e taşıyarak 105. sayıdan itibaren dergiyi burada çıkarmaya başladı ${ }^{45}$. Tüm bu süre zarfında gerek Londra'da gerekse Paris'te Ermeni Sorunu'nu gündeme taşımaya çalışan Çeraz, ilk andan itibaren Osmanlı Hariciyesi'nin de dikkatini çekti. Başlangıçta Londra'da ayda iki kez İngilizce ve Fransızca yayınlandığı haber alınan dergi konusunda Londra Büyükelçisi Rüstem Paşa önce tüm çabalarına rağmen derginin nüshalarını elde edememiş, daha sonra İran ortaelçisi vasıtasıyla eline geçen nüshaları Hariciye Nazırı Said Paşa'ya göndermişti ${ }^{46}$.

Minas Çeraz dergisini İngiltere'de yayınladığı yıllarda Osmanlı Devleti'ne karşı öteden beri menfi politikalar üreten W. E. Gladstone'un sözcüsü gibi yayın yapan liberallerin gazetesi London Daily News'e paralel bir yayın politikası ile çıkardı $\imath^{47}$. Yani Armenie dergisinin yayın

\footnotetext{
${ }^{43}$ Armenia ve Portakalyan konusunda bkz. Jean-Louis Mattei, "Mıgırdiç Portukalyan ve "Armenia" Gazetesi (Terörizmden Şüpheli Ilımlığa)", Ermeni Araştırmaları Dört Aylık, Tarih, Politika ve Uluslararası ilişkiler Dergisi, Sayı 42, Ankara 2012, s. 47-77.

44 Karabet Agopyan'ın faaliyetleri konusunda bkz. Zeynep İskefiyeli, "Ermeni Vatanperver Cemiyeti ve Karabet Agopyan'ın Faaliyetleri", Tarihte Ermeniler ve Ermeni Meselesi, Ed. Bünyamin Kocaoğlu, Samsun, 2017, s. 221-259.

45 L'Intransigeant, "Echos\&Nouvelles", 6 Mai 1898, s. 2.

46 BOA, HR. SYS, 2823/3, BOA, HR. SYS, 2751/51.

47 Orhan Koloğlu, Avrupa Kıskacında Abdülhamid, İletişim Yayınları, İstanbul, 1998, s. 158.
}

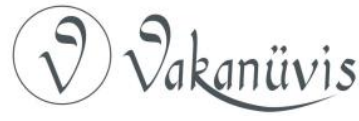


politikası başından itibaren, Ermeni Davası'na taraftar kazanmaya yönelikti ve çeşitli haberler, mektuplar, tarihi konular ve daha birçok husus dergide Ermeni Sorunu çerçevesinde işleniyordu. Minas Çeraz yazı dizisi şeklinde kendi başından geçenleri de dergiye konu ediyordu. Mesela 1901 yılı boyunca Berlin Kongresi'nden sonra Nerses Varjabedyan'ın kendisini İngiltere'ye özel temsilcisi olarak gönderdiği ve başından geçenleri anlattığı, "Une Mission Politique en Angleterre" başlıklı yazı dizisi bunun en güzel örneğidir. İngiltere'de bulunduğu süre zarfında görüştüğü İngiliz siyasiler ve tanınmış kimselerle yaptığı toplantılar hakkında gün be gün detaylar vermesi İngiltere'de o sırada Ermeni Sorunu'na bakışı ortaya koyması açısından kayda değerdir ${ }^{48}$. Minas Çeraz bir yandan kendi dergisini yayınlarken, öte yandan hem Ingiltere ve Fransa'da, hem Avrupa'nın diğer ülkeleri ile Amerikan gazetelerine haber olarak, Ermeni Sorunu'nu gündemde tutmaya çalışmıştır. Bu haberleri zaman zaman kendi dergisinde de yayınlamıştır. Mesela, Dagblad gazetesine verdiği bir röportajı, kendi dergisinde yayınlayan Çeraz, Abdülhamid yönetiminin Pan-İslamizm politikasını güçlendirerek, Hıristiyan milletleri ezdiği imajını şu sözlerle öne çıkarmıştır. "Mevcut Sultan tahta çıkmadan önce, Osmanlılar, daha önce isimleri bile hiç duyulmamış olan, Okyanusya adalarındaki Müslümanların varlığından habersizdi. Ancak, Cava ve İstanbul arasında ticari bir ilişki bulunmamasına rağmen, Abdülhamid Batavia'ya Müslüman bir murahhas gönderdi; bu kişi de Bab-ı Ali'nin orada Panislamist propagandasını teşvik etmek için Cava'daki bazı Müslümanların Osmanlı vatandaşlığını benimsemelerini sağladı. Cava Müslümanları, Hıristiyanlarla savaşması için Osmanlılara büyük meblağlar göndermiştir" ${ }^{49}$.

Çeraz'ın bu menfi tutumu daha çok İngiliz, Fransız ve Amerikan gazetelerinde yayınlanan haberlerde dikkati çekmektedir. Örneğin Ingiliz Newcastle Chronicle gazetesinde, verdiği bir ders ilginç, vurucu ve düşündürücü ifadelerle sütunlara taşınmıştı. "Ermeniler: Memleketleri, Kökenleri, Tarihi, Dini, Dili ve Edebiyatı" başlıklı yazıda, Çeraz çok ilginç ifadelere yer vermiştir. Konuşmasının başlangıcında Ermenistan diye

\footnotetext{
48 Ayrıntılar için bkz. L'Armenie, "Une Mission Politique en Angleterre", JanvierDécembre 1901.

${ }^{49}$ L'Arménie, "La Conférence de la Paix", 1 Août 1899, s. 1.
}

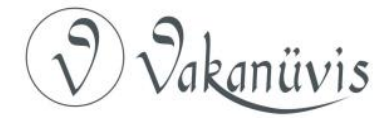


tabir ettiği bölgenin tarihi, coğrafyası, iklimi hakkında bilgi veren Çeraz çekinmeden İngilizlere Anadolu'yu kolonileştirmeleri çağrısı yaptığı ve aslında zihni arka planını ortaya koyduğu şu düşündürücü ifadeleri dile getiriyordu: "Ingilizler böyle verimli ve potansiyel olarak zengin memleketi sömürge haline getirebilir... Birçok Ermeni ingiltere Kraliçesi'nin Ermenistan'ı kendi krallığına neden katmadığını merak ediyor. Ingilizler elan Kıbrıs'talar. Birkaç alay askerini karaya çıkarsalar hilalin boyunduruğundan kurtulmak için cesur dağlı Ermenilere yardım edebilirler" ${ }^{\prime 50}$.

Konuşmalarının yanı sıra İngiliz siyasilere gönderdiği mektuplar da gazetelerde yer alıyordu. Daily News gazetesine yansıyan Gladstone'a gönderdiği bir mektubunda, Türklerin Ermenileri katlettiği savını işlemiştir. Mektuptaki iddialarını Türklerin Van'daki Varak Manastırı'nı altüst edip rahiplerini tartakladıkları, Toprakkale Kilisesi'ni kirlettikleri şeklinde sürdüren Çeraz, Türklerin kapısındaki haçtan tutun içindeki sunağa kadar Bitlis Kilisesi'ni aşağıladıkları iddiasında bulunmuştur. Çeraz, varlığını Avrupalı Hıristiyan devletlerin kendisini korumasına borçlu olduğunu söylediği Osmanlı'nın, Avrupa'nın bu tutumuna rağmen, kendi Hıristiyan halkını "sistematik bir şekilde yok ettiğini" ileri sürmüştür ${ }^{51}$. Gladstone ise verdiği yanıtta kendisinden beklenen bir tavır sergilemiştir. Ermenilere yönelik bilindik pozitif ifadelerini tekrar ettikten sonra eski başbakan İngiltere'nin kendisine ağır faturası olan Türkiye'ye verilen bu desteği çekebileceğine kanaat getirdiğini, hiç bir ümidin kalmadığını ve mevcut yönetim anlayışının eskiden daha kötü olduğunu ileri sürdü ${ }^{52}$. Yine bu sırada Çeraz'ın Agopyan ile birlikte Ingiltere'deki Ermeni cemaati adına altına imza attıkları, Gladstone'un destekçisi Daily News'te Alman İmparatoru'na yönelik 6 Eylül 1890 tarihli bir yazıları yayımlandı. Yazıda Berlin'de alınan ıslahat kararının yerine getirilmediği, Ermenilerin durumunun iyileştirilmesi için Berlin

\footnotetext{
50 Joan George, Merchants in Exile: The Armenians in Manchester, England, 1835-1935, Taderon Pr., 2002, s. 69.

${ }^{51}$ BOA, HR.SFR3., 363/49.

52 BOA., YA. HUS. 273/104, L'Universe, "Dépêches Télegraphiques", 17 Septembre 1890, s. 3.
} 
Antlaşması'nda imzası olan devletlerin sorumluluk alması gerektiği isteniyor, imparatorun kendisinden yardım talep ediliyordu ${ }^{53}$.

Minas Çeraz'ın Amerikan gazetelerinde çıkan haber ve röportajları da Ermeni propagandasına yönelikti. Özellikle Ermeni İsyanları esnasında Çeraz'ın Osmanlı yönetimini batıya şikayet eden katliam temalı haberlerinin sayısı artıyordu. Mesela Ocak 1895 'te Indianapolis Journal'a verdiği röportajda Sasun'daki on bir köyde Kürtlerin erkek, kadın ve çocuk 750 kişiyi kılıçtan geçirdiklerini, aldığı duyuma göre Zeki Paşa'nın Ermenileri kandırarak onları Türklere katlettirdiğini ileri sürüyordu. Menfi imajı perçinlemek için Türklerin Ermeni kadınlara tecavüzü, 60 erkeği kılıçtan geçirdiği, köylerdeki dört Ermeni kilisesini yaktıklarını şeklindeki iddialarını sıralayan Çeraz Türklerin, Hıristiyanlık vurgusuyla Sasun'da geriye kalan otuz üç köyü yağmalamaya devam ettiklerini hatta bu saldırı esnasında bir rahibin kör edilip o şekilde oynamaya zorlanıp, ilahi okuduğu esnada kılıçla paramparça edildiğini ileri sürdü54. Bu süreçte Çeraz'ın Batı gazetelerinde yayınlattığı daha birçok haber ve röportajda benzer savları ileri sürdüğü dikkatlerden kaçmaz. Örneğin Şubat ayının başında bir Amerikan gazetesi Londra'dan Armenie'nin editörü Minas Çeraz'dan gelen haber şeklinde sütunlarına taşıdığı bilgilere göre Çeraz'ın özel muhabiri Ermenilerin katliamlarının devam ettiğini bildirmişti. Bu haberde de Türklerin Ermeni erkekleri öldürüp, kadınları aldıkları, Kürtlerin yerel bazda tanınmış Ermeni liderlerini katlettikleri ileri sürülüyordu. Yine aynı haberde Van'dan alınan bilgiye göre 200 siyasi mahkum Ermeni'ye de, falakaya yatırmak, kızgın demirle dağlamak, soğuk havada çıplak bir şekilde dışarıya çıkarmak gibi türlü çeşitli işkenceler yapılıyordu. Öyle ki gazete bile Van'daki hadiseyi sunarken, iddiaları "başka bir hikaye" şeklinde okuyucularına aktarırken, Washington Times aynı haber için "Ermeni Söylentileri" başlığını kullanıyordu ${ }^{55}$.

\footnotetext{
53 BOA, HR.SFR3., 363/55, London Daily News, "The Armenian Appeal to The German Emperor", 6 October 1890, s. 3.

${ }^{54}$ The Indianapolis Journal, "Deceived by Zekki", 6 January 1895, s. 5.

${ }^{55}$ The Morning News, "More Bloody Works by Turks, The Massacre of Armenians Still in Progress", 18 February 1895, s. 1, The Washington Post, "More Armenian Rumors", 18 February 1895, s. 1.
}

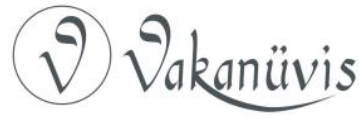


Çeraz Sasun'da meydana gelenleri araştırmak için oluşturulan komisyonun çalışmalarına yönelik olumsuz bir hava oluşturmak adına yine Şubat 1895 'te Amerikan gazetelerinde Türklerin, komisyonun soruşturacağı Ermeni ailelere rüşvetler verdiği ve böylece durumu örtbas etmeye çalıştıkları iddiasında bulundu. New York Times ve Sun gazetelerinde yayınlanan haberlerde bu bilgilerin Çeraz'a özel bir muhabir vasıtasıyla ulaştırıldığı kaydediliyordu ${ }^{56}$. Bu haberlerden de anlaşılacağı üzere Minas Çeraz Amerika'da da Ermeni Davası'nın propagandasını Londra'dan yönlendiren kişi olarak sivrilmiştir. Nitekim bu süreçte Anadolu'da meydana gelen hadiseleri batıya aktaran bir haber kaynağı gibi hareket etmişti. Mesela Central News haber ajansı Anadolu'daki haberi Minas Çeraz vasıtasıyla elde ettiğini ifade ediyor ${ }^{57}$, Çeraz ise ajansın temsilcisine daha sonra Daily News'te yayınlanacak olan Ermeni Sorunu ve ıslahat meselesiyle ilgili görüşlerini aktarıyordu ${ }^{58}$.

Minas Çeraz'ın bu süreçte verdiği en ilginç röportajlardan biri 4 Aralık 1895 'te New York Herald gazetesinin Paris'te çıkan Avrupa nüshasında yayınladı. "Askeri İşgal" başlığıyla verilen haberde, Osmanlı Devleti'nde düzeni sağlamanın tek yolunun askeri işgal olduğunu vurguluyordu. Sultan Abdülhamid'in yetersiz olduğunu ve düzenin sağlanması için ikili/iki yönlü bir işgalin gerekli olduğunu söyleyen Çeraz, Ermenilerin katledildiği temasını işlediği röportajında işgalin İngiltere ve Rusya tarafından yapılması gerektiğini vurgulamıştır. Buna karşılık kendisine yöneltilen "işgali yapan ülkeler arasında rekabet olmaz mı ?" sorusuna, bunun ciddi bir endişe kaynağı olabileceğini ancak Rusya'nın Doğu Anadolu'yu, İngiltere'nin ise Kilikya bölgesini geçici olmak kaydıyla işgal edip, durum düzeldikten sonra bölgeden ayrılabileceklerini ifade etmişti ${ }^{59}$.

Minas Çeraz'ın bu tavrını Fransız gazetelerine yansıyan haberlerde de görmek mümkündür. Aralık 1895 'te yayınlanan bir Fransız gazetesindeki haberde Minas Çeraz'ın dindaşlarının katledilmesi

\footnotetext{
56 The New York Times, "Bribing The Armenians", 23 February 1895, s. 6, The Sun, "Turks Bribing Armenians", 23 February 1895, s. 3.

${ }^{57}$ The Manchester Guardian, "The Alleged Atrocities in Armenia", 12 February 1895, s. 7.

58 BOA., HR. SFR. 433/13, HR. SYS. 2756/51.

59 The New York Herald, "Military Occupation", 4 December 1895, s. 1.
} 
hakkında ilginç bilgiler veren bir konuşma yaptığı ifade edilmektedir ${ }^{60}$. Sasun sonrasında gösterdiği tavrı Osmanlı Bankası Baskını sonrasında da devam ettiren Çeraz'ın verdiği röportaj bu menfi yaklaşımını ortaya koymaktadır. Berlinerr Tageblatt'tan yapılan alıntıyı sayfalarına taşıyan Fransız gazetesindeki haberde, Minas Çeraz olayların müsebbibi olarak Abdülhamid'i gösterme gayreti içerisindedir. Başından beri Ermenileri kışkırtanın Abdülhamid olduğu, suçu olmayan Ermenileri idam ettirdiği, Van'da gerçekleştiğini ileri sürdüğü katliamı yapanları nişanlarla ödüllendirdiği gibi iddialar ileri süren Çeraz, Ermenilerin çok hürmet ettiği İzmirliyan'ı patriklikten alıp yerine öfkeye sebep olan birini tayin ettiğini ifade etti. Röportajın sonunda sözlerini İstanbul'daki komiteci sayısının 12.000 olduğunu ve komitecilerin "Sultan'ın vahşeti ve Avrupa'nın korkaklığını" protesto etmek için bu olayları organize ettiklerini söyleyerek tamamladı ${ }^{61}$. Aynı röportajı yayınlayan Manchester Guardian ise Çeraz'ın olayın organize edilme sebebini "Parmaklarını Avrupa'nın gözlerine sokmak istediler" özdeyişiyle aktardığını kaydediyordu ${ }^{62}$. Dönemin Avrupa ve Amerika gazetelerinde Minas Çeraz hakkında veya bizzat kaynak olarak kendisinin isminin geçtiği onlarca haberde işlenen tema yukarıda verilen örneklerde olduğu gibi, Ermenilerin katliama uğradığı ana fikirli olup, Ermeni ırkının üstün hasletlerinden bahseden, Hıristiyanlığına vurgu yapılan ve batılı ülkelerin meseleye müdahil olması gerektiğinin altını çizen haberlerdir.

\section{Sonuç}

Ermeni Sorunu'nun uluslararası bir hal aldığı Berlin Kongresi ve meselenin krize dönüştüğü 1880 ve bilhassa 1890'lardaki faaliyetleriyle bu sürecin önemli simalarından biri olan Minas Çeraz, Ermeni Davası'nı daha ziyade Dünya kamuoyuna duyurma noktasında çaba göstermiştir. Sarraf bir aileden gelen Minas Çeraz iyi bir eğitim aldıktan sonra birkaç yabancı dil bilmesi nedeniyle Berlin Kongresi'ne giden heyette yer alarak uzun yıllar Ermeni Sorunu'na batılı devletlerin dikkatlerini çekme çabası içerisinde olmuştur. Bu çerçevede Berlin'e giden heyetin tercümanı olarak Avrupa başkentlerinde heyete mihmandarlık etmiş, İtalya,

\footnotetext{
60 Le Matin, "Pour Les Armeniens", 28 Decembre 1895, s. 2.

61 Le Radical, "Derniere Heure", 31 Août 1896, s. 2.

62 The Manchester Guardian, "The Armenian Outbreak at Constantinople", 29 August 1896, s. 7.
}

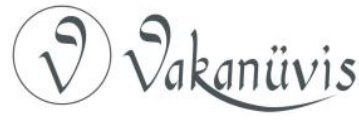


Fransa, İngiltere ve Almanya'da çalınabilecek tüm kapıları çalmıştı. Kısa bir süre sonra yine aynı misyonla İngiltere'ye gönderilen Çeraz burada da Ermeni Davası'na taraftar kazanmak adına Gladstone ve James Bryce gibi etkili İngiliz ileri gelenleri ve devlet adamları ile görüşmeye çaba göstermiş̧ir.

Ülkeye döndükten sonra 1889 'da Londra'ya kaçtığı tarihe kadar öğretmenlik mesleğiyle iştigal eden Çeraz'ın ülkeden gidişinin Ermeni komitelerinin fiili başkaldırı tarihlerine denk gelmesi şaşırtıcı değildir. 1890 'dan itibaren İstanbul ve Anadolu'da meydana gelen isyan boyutuna ulaşan hadiseler esnasında meseleyi uluslararası kamuoyuna taşıma noktasında katıldığı her programda, gittiği her yerde, yaptığı her konuşmada Ermenilerin katledildiği vurgusunu yapmıştır. 1893'te Chicago'da yapılan Dünya Dinler Konferansı, ardından Fransa ve Londra'da tertip edilen konferans ve konuşmalarında ve 1899 'da katıldığı Lahey Barış Konferansı'nda Ermeni Sorunu'na dikkat çekmek için aynı temayı işlemiştir. Bir anlamda güttüğü davasının propagandasını yapan Çeraz, bu süreçte fark ettiği basının gücünden de yararlanmayı ihmal etmedi.

Londra'ya gittiği yıl çıkarıp on yedi yıl yayınladığı dergisini yine bu amaç doğrultusunda kullandığı bir araca dönüştürdü. Bu dönemde kitle iletişim aracı olarak kamuoyu oluşturma noktasında etkisi giderek artan gazetenin bu mühim özelliğini fark ettiği için gerek Avrupa gazeteleri ve gerekse Amerikan gazetelerinde her firsatta Ermeni Davası'nın propagandasını yapmıştır.

İyi eğitimli, çok dil bilen, öğretmenlik, yazarlık ve gazetecilik gibi farklı özellikleri olan devrinin aydın profiline uygun bir kişilik görüntüsü çizen Minas Çeraz'ın Batı'da Ermeni Sorunu'nu gündeme getirmek için tüm gayretiyle çaba göstermesi, Osmanlı Devleti'nde o sırada benzer gayeler güden aydın profilinin iyi bir örneğidir. Kısacası Çeraz 19. yüzyılın son çeyreğinde milliyetçilik cereyanından etkilenmiş çok uluslu imparatorluklarda yaşayan farklı etnik gruplara mensup bir aydın profili çizmektedir.

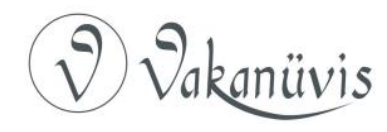




\section{Kaynakça}

\section{Arşiv Belgeleri}

BOA, HR. SYS, 2751/51.

BOA, HR. SYS, 2823/3,

BOA, HR.SFR3., 363/55.

BOA., BEO. 292/21830.

BOA., HR. SFR. 363/49

BOA., HR. SFR. 433/13.

BOA., HR. SYS. 2751/16.

BOA., HR. SYS. 2756/51.

BOA., HR.SFR3., 363/49.

BOA., HR.SYS. 2736/8.

BOA., Y.Mtv. 193/33.

BOA., Y.PRK. HR. 27/93-94,

BOA., YA. HUS. 273/104

BOA., YA.HUS. 281/103.

BOA., Y.PRK.A., 3-25.

\section{Süreli Yayınlar}

Chicago Daily Tribune

L'Arménie

L'Intransigeant

L'Universe

Le Grand Echo du Nord,

Le Journal

Le Journal des Débats Politiques et Littéraires.

Le Matin

Le Petit Caporal

Le Petit Marseillais

Le Radical

Le Rappel

Le Temps

Leamington Spa Courier

Les Nouvelles D'Orient

London Daily News

Morning News

Paris-Soir

Rock Island Daily Argus

The Indianapolis Journal

The Manchester Guardian

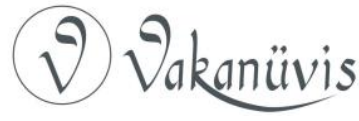


The New Armenia

The New York Herald

The New York Times

The Sun

The Washington Post

\section{Kitaplar ve Makaleler}

BARDAKJIAN, Kevork B., A Reference Guide to Modern Armenian Literature 1500-1920, Wayne State University Press, Detroit, 2000.

BARROWS, John Henry(Ed.), The World's Parliament of Religions Vol. I, The Parliament Publishing Company, Chicago, 1893.

CARUS, Paul, The Dawn of a New Religious Era, The Open Court Publishing Company, Chicago, 1916.

GEORG, Joan, Merchants in Exile: The Armenians in Manchester, England, 1835-1935, Taderon Pr., 2002.

GÜLLÜ, Ramazan Erhan, Ermeni Sorunu ve Istanbul Ermeni Patrikhanesi (1878-1923), Türk Tarih Kurumu, Ankara 2015.

HACIKYAN, Agop J. vd., The Heritage of Armenian Literature Vol. III, Wayne State University, Detroit, 2005.

iSKEFIYELi, Zeynep, "Ermeni Vatanperver Cemiyeti ve Karabet Agopyan'ın Faaliyetleri", Tarihte Ermeniler ve Ermeni Meselesi, Ed. Bünyamin Kocaoğlu, Samsun, 2017, s. 221-259.

KARENTZ, Varoujan, Mitchnapert the Citadel: A History of Armenians in Rhode Island, iUniverse, 2004.

KNADJIAN, H.M., The Eternel Struggle, Fresno Republican Printery, California, 1900.

KRBEKYAN, V.G., "Armyanskiy Vopros na Berlinskom Kongresse”, Lraber Hasarakakan Gitut'yunneri, Yerevan, 2002.

MARSHALL, Annie C., "Minas Cheraz, A Biographical Sketch”, Armenia, Vol. XI, No. 8, March 1913.

MATTEI, Jean-Louis, "Mıgırdiç Portukalyan ve "Armenia" Gazetesi (Terörizmden Şüpheli Ilımlığa)", Ermeni Araştırmaları Dört Aylık, Tarih, Politika ve Uluslararası ilişkiler Dergisi, Sayı 42, Ankara 2012, s. 47-77.

PAMUKCIYAN, Kevork, Biyografileriyle Ermeniler, Aras Yayıncılık, İstanbul, 2003.

PARSAMIAN, Vardan Aramovic, Istoria Armianskogo Naroda 1801-1900 gg. Erivan, 1972.

SAKIN, Serdar, "Minas Çeraz'ın (Minasse Tcheraz) Avrupa Temasları ve Berlin Kongresi İzlenimleri", Gazi Akademik Bakış, Cilt. 8, Sayı 16, 2015, s. 237258.

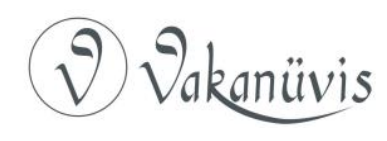


SARKISSIAN, A. O., History of the Armenian Question to 1885, Urbana : the University of Illinois Press, 1938.

ŞAŞMAZ, Muşa, British Policy and the Application of Reforms for the Armenians in Eastern Anatolia 1877-1897, Türk Tarih Kurumu, Ankara, 2001.

TCHERAZ, Minas, Conférence Arménienne a Amsterdam, Libraire Höveker\&Wormser, Amsterdam, 1899.

TUĞLACI, Pars, Ermeni Edebiyatından Seçkiler, Cem Yayınevi, İstanbul, 1992.

URAS, Esat Tarihte Ermeniler ve Ermeni Meselesi, Belge Yayınları, İstanbul 1987. 


\section{EKLER}

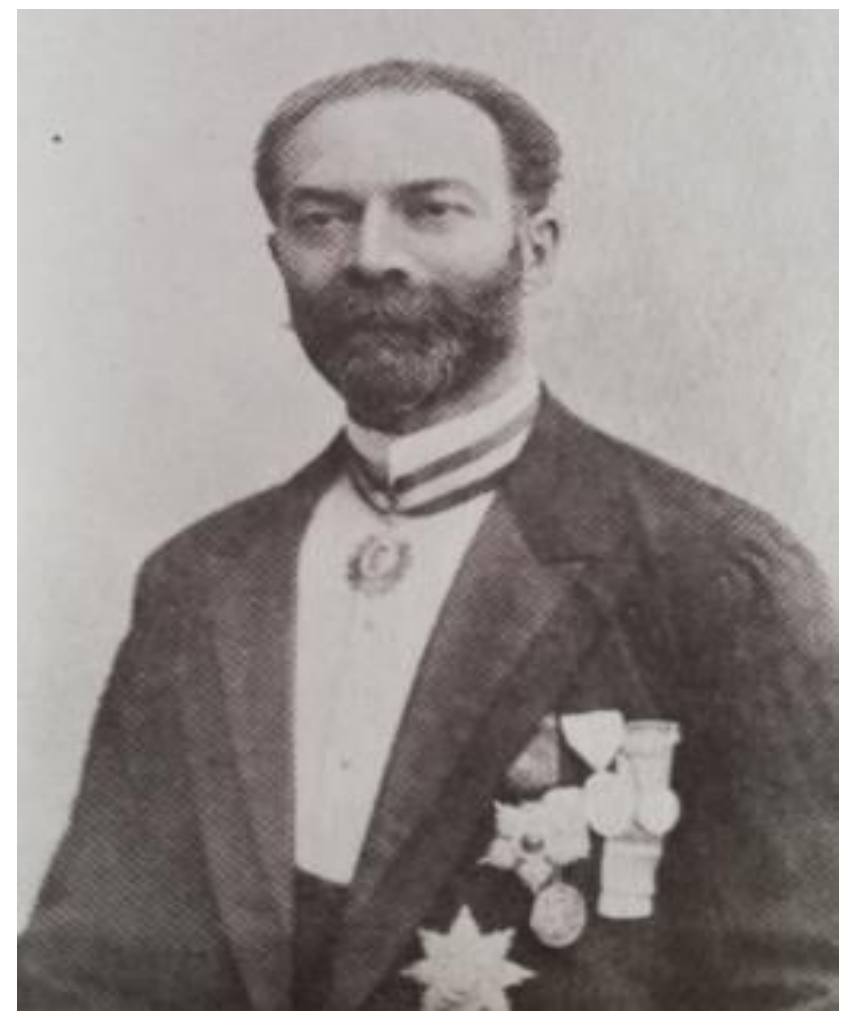

Ek 1: Minas Çeraz

(Pars Tuğlacı, Ermeni Edebiyatından Seçkiler, Cem Yayınevi, İstanbul, 1992, s. 88) 


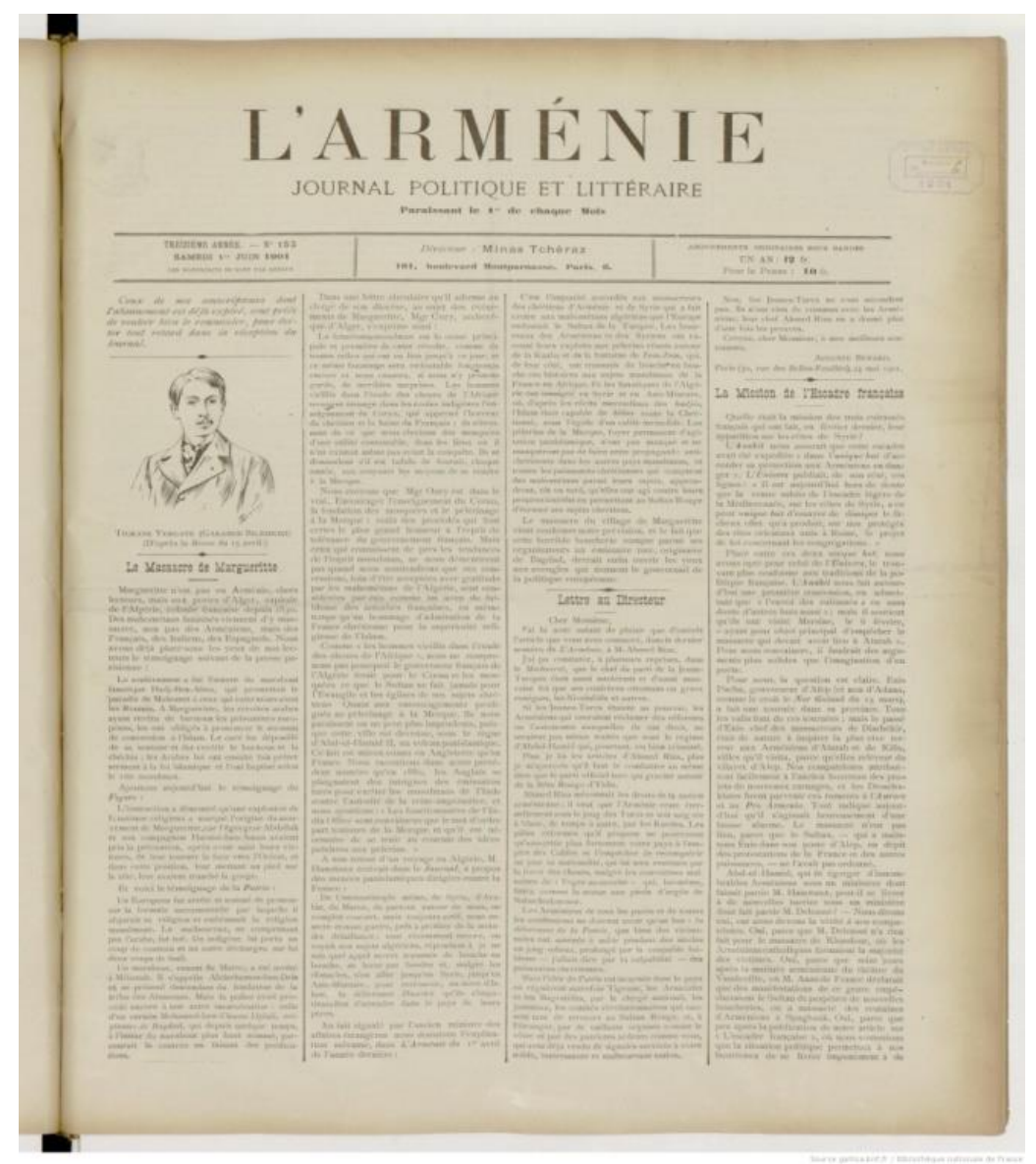

Ek 2: Minas Çeraz'ın 17 yıl boyunca çıkardığı L'Arménie dergisi

(L’Arménie, 1 Juin 1901, s. 1) 


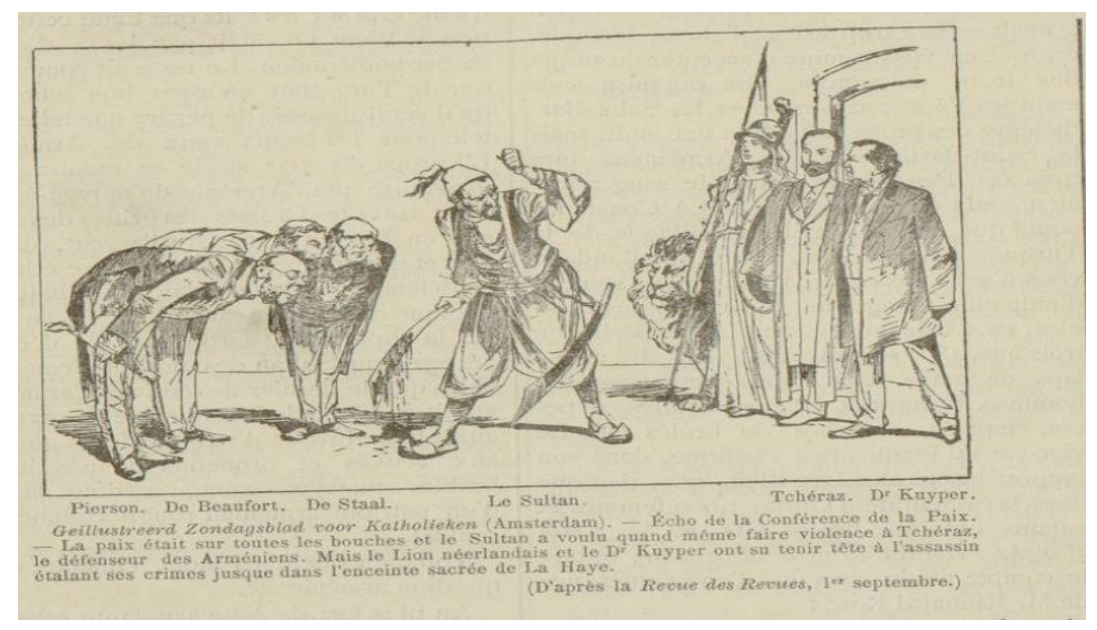

Ek 3: Sultanın, Ermenilerin savunucusu olan M. Çeraz'a şiddet uygulamak istediği ancak Dr. Kuyper ve Hollanda aslanının onu koruduğuna yönelik karikatür.

(L’Arménie,1 Octobre 1899, s. 1) 